\title{
Certified Crop Advisors' Perceptions of Giant Ragweed (Ambrosia trifida) Distribution, Herbicide Resistance, and Management in the Corn Belt
}

\author{
Emilie E. Regnier, S. Kent Harrison, Mark M. Loux, Christopher Holloman, Ramarao Venkatesh, \\ Florian Diekmann, Robin Taylor, Robert A. Ford, David E. Stoltenberg, Robert G. Hartzler, \\ Adam S. Davis, Brian J. Schutte, John Cardina, Kris J. Mahoney, and William G. Johnson*
}

Giant ragweed has been increasing as a major weed of row crops in the last $30 \mathrm{yr}$, but quantitative data regarding its pattern and mechanisms of spread in crop fields are lacking. To address this gap, we conducted a Web-based survey of certified crop advisors in the U.S. Corn Belt and Ontario, Canada. Participants were asked questions regarding giant ragweed and crop production practices for the county of their choice. Responses were mapped and correlation analyses were conducted among the responses to determine factors associated with giant ragweed populations. Respondents rated giant ragweed as the most or one of the most difficult weeds to manage in $45 \%$ of 421 U.S. counties responding, and 57\% of responding counties reported giant ragweed populations with herbicide resistance to acetolactate synthase inhibitors, glyphosate, or both herbicides. Results suggest that giant ragweed is increasing in crop fields outward from the east-central U.S. Corn Belt in most directions. Crop production practices associated with giant ragweed populations included minimum tillage, continuous soybean, and multipleapplication herbicide programs; ecological factors included giant ragweed presence in noncrop edge habitats, early and prolonged emergence, and presence of the seed-burying common earthworm in crop fields. Managing giant ragweed in noncrop areas could reduce giant ragweed migration from noncrop habitats into crop fields and slow its spread. Where giant ragweed is already established in crop fields, including a more diverse combination of crop species, tillage practices, and herbicide sites of action will be critical to reduce populations, disrupt emergence patterns, and select against herbicide-resistant giant ragweed genotypes. Incorporation of a cereal grain into the crop rotation may help suppress early giant ragweed emergence and provide chemical or mechanical control options for late-emerging giant ragweed. Nomenclature: Glyphosate; giant ragweed, Ambrosia trifida L. AMBTR; common earthworm, Lumbricus terrestris L.; corn, Zea mays L.; soybean, Glycine max (L.) Merr.

Key words: Allergy, asthma, crop rotation, nightcrawler, postemergence herbicide, tillage practice, weed adaptation, weed emergence.

Giant ragweed, a member of the Asteraceae family, causes severe agronomic and health costs, has developed herbicide resistance, and is expanding as a crop weed in its native range in North America. It is one of the most competitive annual weeds in corn, soybean, and cotton (Gossypium hirsutum L.) in the United States, causing yield losses of over $50 \%$ in corn and more than $75 \%$ in soybean and cotton at a population of only 1 plant $\mathrm{m}^{-2}$ (Barnett and Steckel 2013; Baysinger and Sims 1991; Harrison et al. 2001; Webster et al. 1994). In addition to crop yield losses, the pollen of giant ragweed and common ragweed (Ambrosia artemisiifolia L.) is a major source of aeroallergens plaguing millions of seasonal allergy sufferers (Arbes et al. 2005; Boulet et al. 1997).

\section{DOI: 10.1614/WS-D-15-00116.1}

* First, second, third, fifth, and eighth authors: Associate Professor, Professor, Professor, Research Associate, and Research Assistant, Department of Horticulture and Crop Science, Ohio State University, 2021 Coffey Road, Columbus, OH 43210; fourth author: Director, Statistical Consulting Service, Department of Statistics, Ohio State University, 1958 Neil Ave., Columbus, OH 43210; sixth author: Assistant Professor, Ohio State University Libraries, 2120 Fyffe Road, Columbus, OH 43210; seventh author: Senior Research Scientist, Texas A\&M AgriLife Research \& Extension Center, 720 E. Blackland Road, Temple, TX 76502; ninth author: Professor, Department of Agronomy, University of Wisconsin, 1575 Linden Drive, Madison, WI 53706; 10th author: Professor, Department of Agronomy, Iowa State University, 2104 Agronomy Hall, Ames, Iowa 50011; 11th author: Research Ecologist, U.S. Department of Agriculture-Agricultural Research Service Global Change and Photosynthesis Research Unit, Urbana, IL 61801; 12th author: Assistant Professor, Department of Entomology, Plant Pathology, and Weed Science, New Mexico State University, 945 College Ave, Las Cruces, NM 88011; 13th author: Professor, Department of Horticulture and Crop Science, Ohio Agricultural and Developmental Center, Ohio State University, Wooster, OH 44691; 14th author: Research Associate, Department of Plant Agriculture, University of Guelph Ridgetown Campus, Ridgetown, Ontario N0P 2C0, Canada; 15th author: Professor, Department of Botany and Plant Pathology, Purdue University, 915 West State Street, West Lafayette, IN 47907. Corresponding author's E-mail: regnier.1@osu.edu 
In the last three decades, giant ragweed has become an increasing concern in the U.S. Corn Belt and midSouth, and in Canada (Bassett and Crompton 1982; Johnson et al. 2006; Page and Nurse 2015; Steckel and Gwathmey 2007; Vink et al. 2012), due in part to the steady increase in herbicide-resistant populations since the mid-1990s (Heap 2015). Giant ragweed is an allogamous, genetically variable species capable of rapid evolution in response to herbicide selection pressure (Brabham et al. 2011; Patzoldt and Tranel 2002). Populations resistant to glyphosate and acetolactate synthase (ALS)-inhibiting herbicides have now been reported in 13 U.S. states and one Canadian province (Heap 2015). Several reports suggest that problems managing giant ragweed and herbicideresistant populations have followed a westward trajectory from the eastern U.S. Corn Belt (Fickett et al. 2013a,b; Heap 2015; Hoskins 2005; Loux and Berry 1991); however, an early survey indicates problems with giant ragweed arose simultaneously in areas separated widely across the U.S. Corn Belt (Jordan 1985).

It is unclear whether the recent increase in giant ragweed is the result of geographic spread of adapted giant ragweed biotypes across the landscape from east to west, or through local adaptations. Although giant ragweed is by origin a riparian species of riverbanks and floodplains (Bassett and Crompton 1982), it often colonizes a variety of nonriparian edge habitats such as fencerows and railroad sidings (Sosnoskie et al. 2007; Venkatesh et al. 2013). These habitats form a loose network throughout much of the Corn Belt and may serve as corridors for spread across the landscape. The development of giant ragweed as a weed in crop fields seems to follow its colonization of edge habitats; however, we have observed that it remains confined to edge habitats in parts of its range, suggesting that the ability of local populations to invade agricultural fields varies across the U.S. Corn Belt.

Adaptations at the local scale may depend on the strength of local selection factors and the availability of genetic variation for adapted traits in local populations. One giant ragweed adaptation observed in the eastern U.S. Corn Belt is a prolonged emergence period, which distinguishes agricultural from successional (e.g., riparian or other nonagricultural) populations (Davis et al. 2013; Schutte et al. 2012; Sprague et al. 2004). Successional populations of giant ragweed in Ohio exhibit an early, short emergence period, whereas agricultural populations exhibit early, extended emergence, typically $>100 \mathrm{~d}$, allowing establishment following early-season weed control practices (Schutte et al. 2008b, 2012; Sprague et al. 2004). In contrast, giant ragweed emergence in Iowa agricultural fields was reported to be early and brief in both successional and agricultural habitats (Sprague et al. 2004; Werle et al. 2014), and a similar early and brief emergence period was observed recently in Nebraska fields (Kaur 2015). There is evidence for genetic variation in emergence phenology (Schutte et al. 2008a). An east to west trend in emergence period is hypothesized to explain the east to west trend in chronology of giant ragweed problems.

Giant ragweed exhibits an association with common earthworm that may also contribute to its establishment in crop fields (Regnier et al. 2008). This burrowing earthworm adds to the active giant ragweed seed bank by collecting and burying the large seeds in its burrows, reducing the risk of seed predation by vertebrates and positioning some of the seeds at optimal depths for emergence and seedling growth (Harrison et al. 2003; Liu et al. 2008; Regnier et al. 2008). The two species were shown to be spatially associated in Ohio, Indiana, and Illinois, and the association was found to be dependent on seasonal rainfall (Schutte et al. 2010). It is unknown if giant ragweed and common earthworm are associated in other parts of the U.S. Corn Belt.

Shifts in crop production practices may have influenced giant ragweed population dynamics over time, and varying crop production practices across the U.S. Corn Belt may exert different selection pressures on local giant ragweed populations (Page and Nurse 2015; Recker et al. 2015). Earlier crop planting over the last several decades (Kucharik 2008) may have encouraged incursions from edge habitats by providing a greater opportunity for establishment by individuals from early-emerging successional populations. Growers in Ohio believe that giant ragweed became more problematic as soybean acreage increased (M Loux, personal communication). Giant ragweed is more competitive and causes greater yield losses in soybeans than in corn (Baysinger and Sims 1991; Harrison et al. 2001; Page and Nurse 2015), and U.S. soybean acreage in 2015 was 35\% greater than in 1995 (USDA-NASS 2015). Since 1996, the widespread adoption of herbicideresistant soybean and corn varieties, earlier planting dates, and a concomitant reduction in tillage have increased growers' reliance on POST herbicides, primarily glyphosate (USDA-NASS 2015). Increased reliance on glyphosate and other POST herbicides may increase selection pressure for late-emerging giant ragweed biotypes because these herbicides are generally applied early in the season and tend to have limited or no soil residual activity (Owen and Zelaya 2005).

Shifts in tillage may also influence giant ragweed soil seed banks. Corn and soybean acreage managed by conservation tillage has approximately doubled 
over the past two decades in the United States (CTIC 2012). Some conservation tillage practices result in an intermediate level of soil disturbance that may place giant ragweed seeds at more optimum depths for survival and emergence, compared to conventional deep tillage or no-tillage practices (Abul-Fatih and Bazzaz 1979; Barnes et al. 2004; Harrison et al. 2003, 2007; Stoltenberg et al. 2011). Reductions in tillage also increase common earthworm populations (Edwards and Bohlen 1996), which may further increase the opportunities for burial of giant ragweed seeds at optimum depths.

A growing body of evidence suggests that geographic variation in the biology and ecology of giant ragweed, and also in crop production practices, may influence giant ragweed populations and spread across the U.S. Corn Belt. Previous studies have demonstrated the value of taking into consideration anthropogenic and biological factors in landscapescale analyses of weed dispersal (Chauvel et al. 2006; Dauer et al. 2009; Lavoie et al. 2007; Pysek and Prach 1995). The objective of this survey study was to determine the pattern of spread of giant ragweed in the U.S. Corn Belt and to assess the contribution of the factors outlined above to problems managing giant ragweed.

\section{Materials and Methods}

Survey Instrument. A Web-based survey of certified crop advisors (CCAs) was used to gather data on the geographic distribution of giant ragweed, herbicideresistant populations, emergence period, presence of common earthworm, and crop production practices. Correlation analyses were conducted among the survey variables to identify ecological and crop production factors associated with giant ragweed populations. The survey was conducted from June 29, 2013, through July 30, 2013. The American Society of Agronomy distributed the survey by E-mail to 7,744 CCAs located in 15 states and in Ontario, Canada (Table 1). A total of 968 CCAs responded to the survey (Table 1). Aggregate response rate was $12.5 \%$ (Table 1), which was similar to the response rate $(10 \%)$ of a Web-based survey on herbicide resistance distributed to CCAs in the United States and Canada (Asmus et al. 2013).

The questionnaire, which is provided in Supplemental Appendix 1 (http://dx.doi.org/10.1614/WSD-15-00116.S1), asked participants to select the county in their state they knew best and to answer questions for the selected county. The survey asked respondents to provide their estimates of crop and
Table 1. Response rate of certified crop advisors (CCAs) to a Web-based survey conducted in 2013. The survey asked questions giant ragweed distribution and biology, and about crop production practices.

\begin{tabular}{lrcc}
\hline State & $\begin{array}{c}\text { Total no. } \\
\text { of CCAs }\end{array}$ & $\begin{array}{c}\text { No. of CCAs } \\
\text { responding }\end{array}$ & $\begin{array}{c}\text { Response } \\
\text { rate }\end{array}$ \\
\hline Arkansas & & & $\%$ \\
Colorado & 168 & 9 & 5.4 \\
Illinois & 1,274 & 11 & 6.3 \\
Indiana & 772 & 165 & 13.0 \\
Iowa & 1,150 & 128 & 16.6 \\
Kansas & 319 & 133 & 11.6 \\
Kentucky & 211 & 18 & 5.6 \\
Minnesota & 666 & 24 & 11.4 \\
Missouri & 319 & 99 & 14.9 \\
Nebraska & 625 & 43 & 13.5 \\
Ohio & 510 & 42 & 6.7 \\
Oklahoma & 93 & 105 & 20.6 \\
Ontario & 510 & 6 & 6.5 \\
Pennsylvania & 154 & 48 & 9.4 \\
Tennessee & 165 & 9 & 5.8 \\
Wisconsin & 632 & 15 & 9.1 \\
Total & 7,744 & 113 & 17.9 \\
\hline
\end{tabular}

noncrop acreage with giant ragweed present (hereafter referred to as giant ragweed abundance), year of first occurrence of giant ragweed in crop fields and in noncrop areas, difficulty of managing giant ragweed, noncrop habitat types with giant ragweed present, month of first and last giant ragweed emergence, and percentage of crop acreage with common earthworm present. In addition, for each of four crop species, participants were asked to provide estimates of the percentage of crop acreage under various tillage, crop rotation, and herbicide strategies, and presence of herbicide-resistant giant ragweed populations. Crop species surveyed included corn, soybean, wheat (Triticum aestivum L.), and cotton.

Tillage practices included conventional $(<30 \%$ residue cover after planting), minimum ( $\geq 30 \%$ residue cover after planting), and no tillage. Crop rotation was defined as the percentage of acreage that had been rotated within the previous 3 yr. Herbicide strategies surveyed included PRE herbicide only (PRE ONLY), POST herbicide only (POST ONLY), PRE and POST herbicide (PRE + POST), one POST herbicide application (1 POST), two POST herbicide applications (2 POST), or more than two POST herbicide applications ( $>2$ POST). Herbicide resistance was defined as either suspected or confirmed by University testing. Respondents were asked about three categories of herbicide resistance: resistance to ALS inhibitors, resistance to glyphosate, and resistance to both ALS inhibitors and

Regnier et al.: Giant ragweed in the Corn Belt • 
glyphosate (i.e., plants having resistance to both sites of action).

Data Analyses. Maps of responses to various survey questions were created to determine their geographic distribution. For ordinal variables, the median response value was mapped. For categorical variables, the mode (randomly selected from among the modes, if more than one mode existed) was mapped. For binary variables, the percentage responding in the affirmative was calculated and then this percentage was dichotomized as either greater than $80 \%$ or not greater than $80 \%$.

Various statistical analysis methods were used to identify production practices and ecological factors associated with giant ragweed problems and to assess the strength of relationship among the variables. Individual respondent data were used for these analyses. The type of analysis conducted on pairs of variables depended on the properties of the variables being compared. For analyses with a continuous dependent variable (e.g., percentage of crop acreage with giant ragweed present) and a continuous or binary independent variable (e.g., length of emergence period), Pearson correlation was used to quantify the strength of association, and a linear model (regression or two-sample $t$ test, depending on the independent variable) was used to test for significance. For analyses with a continuous dependent variable and an ordinal independent variable (e.g., years since first occurrence in crop fields, which was divided into several categories), Spearman correlation was used to quantify the strength of association and an ANOVA $F$ test was used to test for significance. For analyses with an ordinal response, Spearman correlation was used to quantify strength; in this case, a cumulative logit model was used to test for significance, treating the independent variable as a categorical factor if its original scale was binary or ordinal. For analyses with a binary response, Pearson and Spearman correlations were used to quantify strength for continuous/binary and ordinal independent variables, respectively; in this case, a logistic regression was used to test for significance treating the independent variable as a categorical factor if its original scale was binary or ordinal. Data were pooled over suspected and confirmed herbicide resistance categories. All statistical computations and mapping were performed using $\mathrm{R}$ Statistical Language software ( $\mathrm{R}$ Development Core Team 2014; R Foundation for Statistical Computing, Wien, Austria).

Data were obtained for a total of 460 counties in the 15 states surveyed. Due to an error, county names in Ontario were not recorded, and therefore, responses from Ontario are not presented in the maps of giant ragweed distribution; however, the Ontario data are included in all statistical analyses (Tables 2-6). For questions that dealt with production factors in crop fields, the following numbers of respondents answered at least one question specific to each crop: corn, 779; soybean, 726; wheat, 496; and cotton, 14. Due to the low number of responses for cotton, these data were excluded from the correlation analyses, but are presented in the maps of giant ragweed distribution. Responses to the questionnaire, pooled over the entire survey area (including Ontario), are provided in Supplemental Appendix 2 (http://dx.doi.org/10.1614/WS-D-1500116.S2).

\section{Results and Discussion}

Giant Ragweed Distribution and Spread. Survey responses indicated that giant ragweed was distributed primarily near the upper Mississippi River and its major tributaries, and north of the Ohio River in Indiana and western Ohio (Figure 1; a reference map with names of states and major rivers is provided in Supplemental Appendix 3: http:dx.doi.org/ 10.1614/WS-D-15-00116.S3). Within crop fields, giant ragweed was most abundant in the east-central region (i.e., $80 \%$ or more crop acreage with giant ragweed present), including western Ohio, Indiana, northwestern Illinois, southwestern Wisconsin, southeastern Minnesota, east-central Iowa, and northeastern Missouri (Figure 1). In this area, giant ragweed was usually more abundant in crop fields than in noncrop environments, whereas the reverse was generally true in the periphery of the surveyed area (Figure 1). Giant ragweed was also reported to have appeared earlier $(>20 \mathrm{yr}$ ago $)$ in the eastcentral region compared to peripheral areas, especially in crop fields (Figure 2). Crop fields with a more recent appearance of giant ragweed ( $\geq 15 \mathrm{yr}$ ago) were located in northern Wisconsin, western Minnesota, western Iowa, Nebraska, Colorado, Kansas, Missouri, Arkansas, Tennessee, and Pennsylvania (Figure 2). In these areas giant ragweed was generally reported to have appeared earlier in noncrop environments compared to crop fields, whereas time of first appearance was usually similar in both environments in the east-central area (Figure 2). Giant ragweed abundance in crop fields was highly correlated with its abundance in noncrop environments (Table 2). Taken together, survey results indicate that giant ragweed growing in crop fields is closely related to giant ragweed growing in noncrop habitats. 

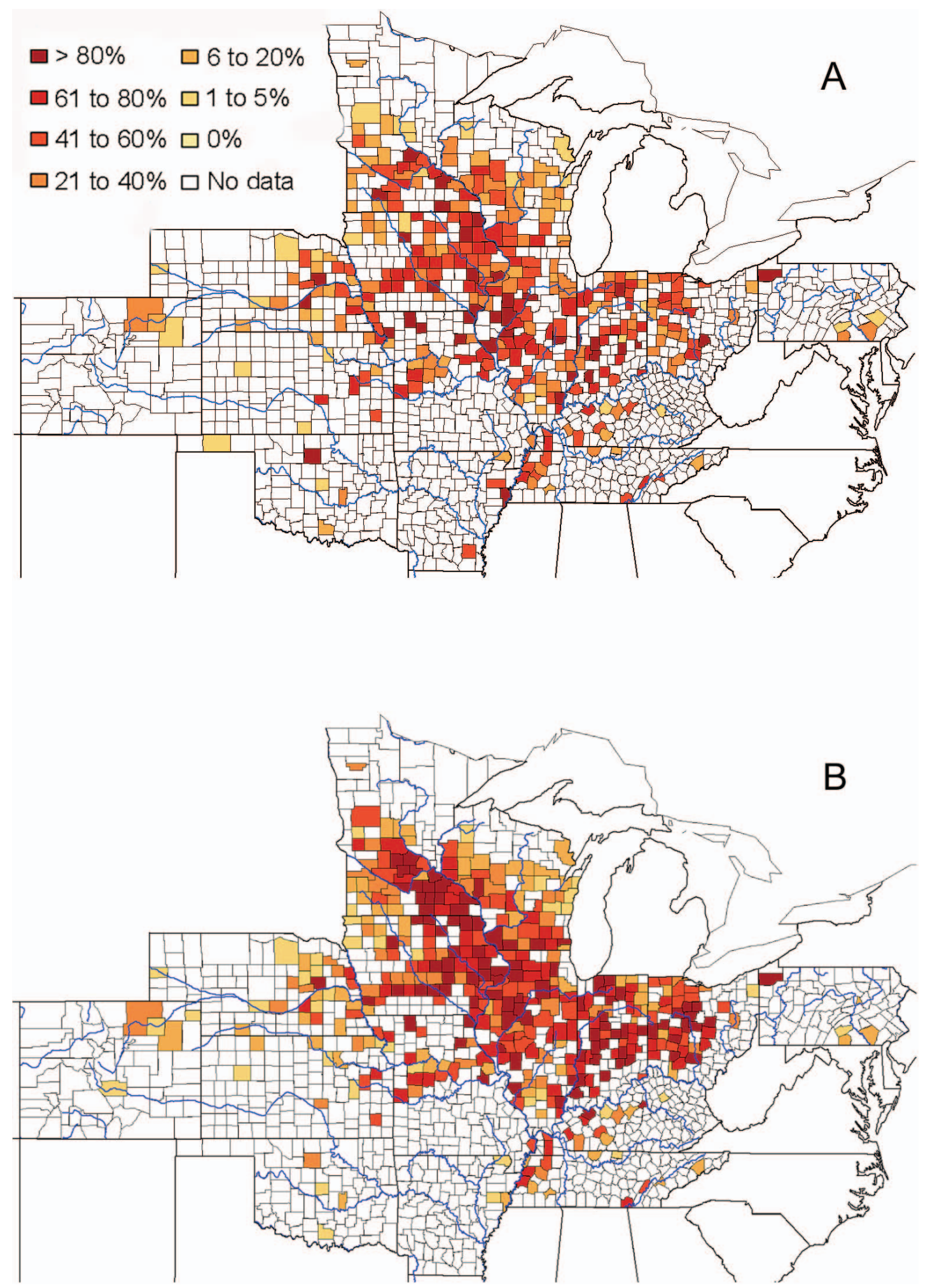

Figure 1. Distribution of survey responses regarding percentage of acreage with giant ragweed present in (A) noncrop habitats and (B) crop fields. For each county, the median response is presented.

The earlier time of appearance of giant ragweed and its greater abundance in crop fields in the eastcentral area compared to peripheral areas suggest that giant ragweed problems in crop fields within the past 20 yr originated primarily in the east-central
Corn Belt. Results indicating the more recent occurrence of giant ragweed in crop fields along most of the perimeter of the survey region show no clear single direction of spread, but rather a spread outward in most directions. In the periphery of the surveyed 

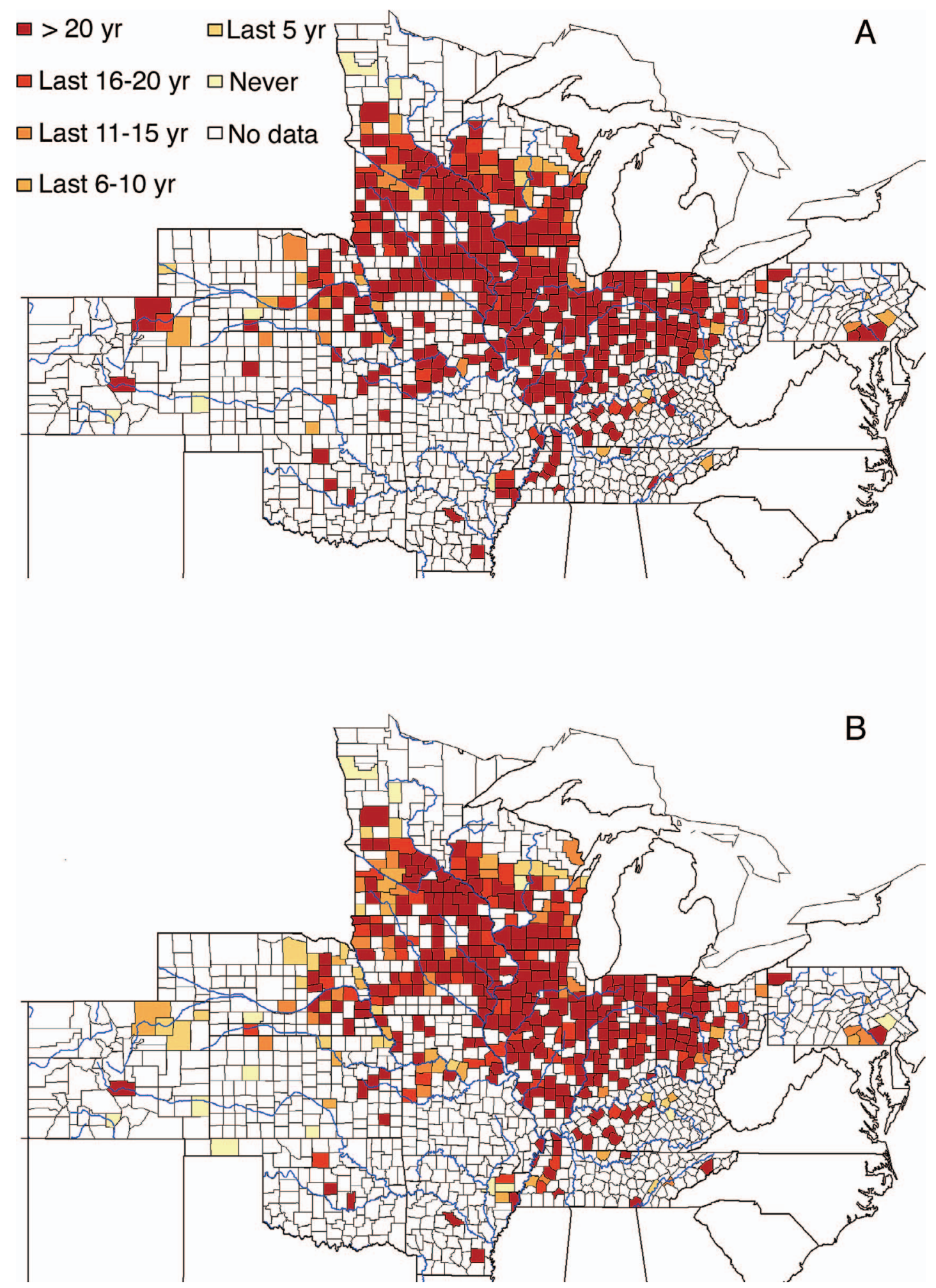

Figure 2. Distribution of survey responses regarding year since giant ragweed first appeared in (A) noncrop habitats and (B) crop fields. For each county, the median response is presented.

region, the greater percentage of acreage with giant ragweed in noncrop habitats compared to crop fields, and its more recent occurrence in crop fields compared to noncrop habitats suggest migration of giant ragweed into crop fields from local noncrop populations, as hypothesized. In the east-central area, the greater abundance of giant ragweed in crop vs. noncrop environments and its early appearance in both environments suggest that giant ragweed populations have shifted from noncrop to crop environments. Researchers in Ontario recently reported a similar shift (Page and Nurse 2015). 

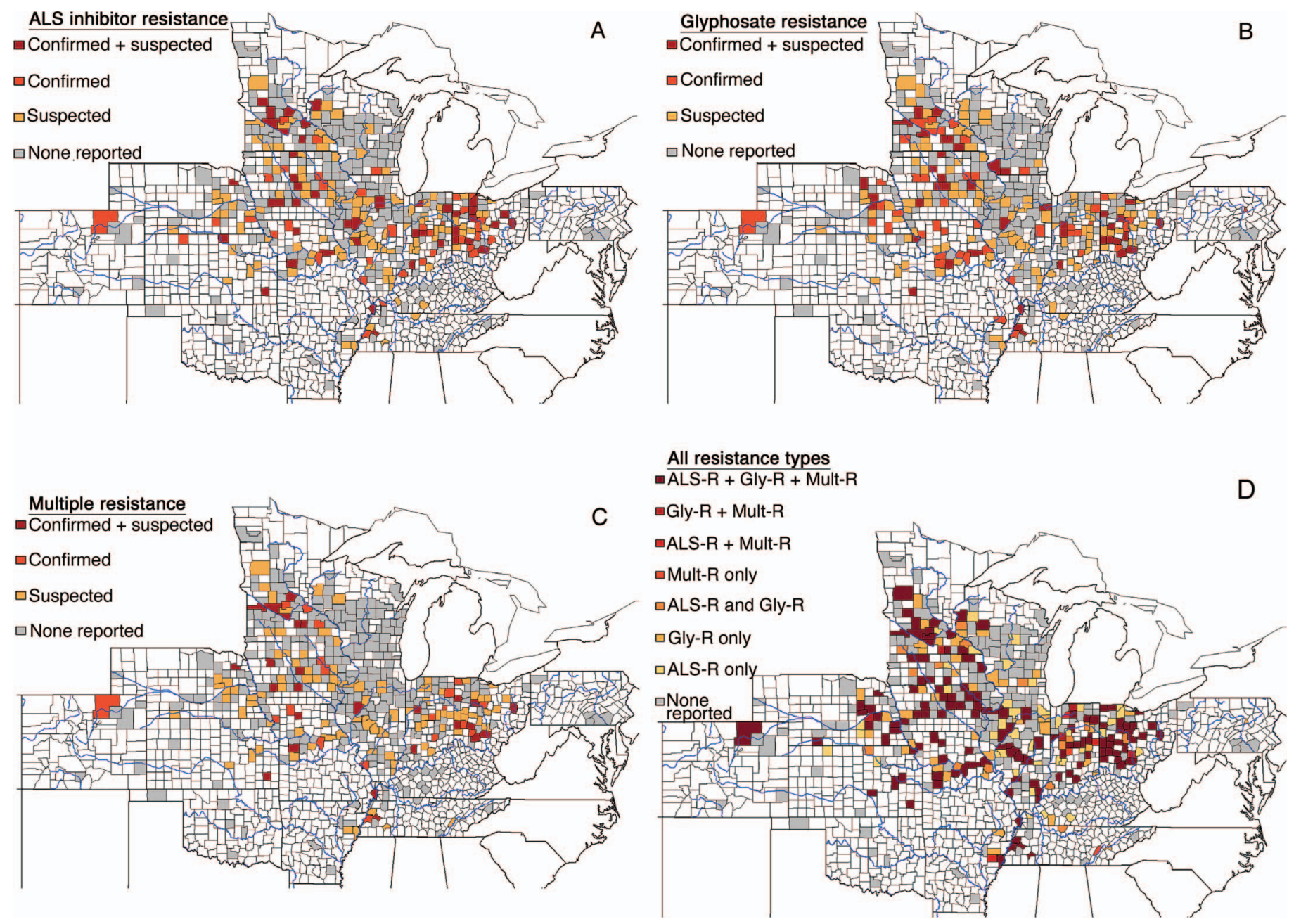

Figure 3. Distribution of respondents' perceptions of the presence of herbicide resistance in corn, soybean, wheat, and cotton fields for (A) ALS-inhibitor resistance, (B) glyphosate resistance, and (C) resistance to both ALS inhibitors and glyphosate (multiple resistance). Participants provided separate responses for suspected resistance and resistance confirmed by university testing. (D) Panel overlays the data shown in panels A, B, and C, combined over suspected and confirmed resistance categories. Data represent the response of $80 \%$ or more of the respondents. Abbreviations: ALS-R, acetolactate synthase-inhibitor resistance; Gly-R, glyphosate resistance; Mult-R, multiple resistance.

Herbicide Resistance. Populations of giant ragweed with either suspected or confirmed herbicide resistance were reported in 57\% of counties responding (232 of 409 counties; Figure 3). Resistance perceived to be confirmed by university testing was reported in 111 counties and resistance that was suspected (but not confirmed) was reported in 121 counties (Figure 3 ). Reports of suspected resistance might reflect limited confirmation efforts, the nascent development of resistant populations in those counties, or both. Based on our experience, it seems likely that many assumptions of resistance without official confirmation are valid. Therefore, in the following discussion, the term "resistance" will refer to both suspected and confirmed resistance.

Of 15 states surveyed, resistance to ALS inhibitors, to glyphosate, and to both modes of action was reported in 13,14, and 12 states, respectively
(Figure 3). In comparison, among the same 15 states, there has been official confirmation of resistance to the same modes of action, respectively, in 5, 11, and 3 states (Heap 2015). Thus, survey results indicate respondents perceive more areas to be affected by herbicide resistance than have been documented officially, particularly resistance to ALS inhibitors and resistance to both ALS inhibitors and glyphosate.

In general, herbicide resistance across different herbicide sites of action was concentrated within the same counties; for example, most of the counties that reported resistance to ALS inhibitors also reported resistance to glyphosate (Figure 3). Clusters of counties reporting multiple modes of resistance occurred in Ohio, Indiana, Illinois, Missouri, Iowa, Nebraska, and Minnesota. There were relatively few reports of resistant populations within a large

Regnier et al.: Giant ragweed in the Corn Belt • 367 
Table 2. Correlation coefficients for correlations between responses to survey questions regarding percentage of crop acreage infested with giant ragweed, difficulty managing giant ragweed, giant ragweed resistance to herbicides, and year(s) since first appearance of giant ragweed. Questions regarding acreage infested and difficulty of management addressed crop species collectively. Questions regarding resistance addressed crop species separately.

\begin{tabular}{|c|c|c|c|c|c|c|}
\hline Survey question & $\begin{array}{l}\text { Crop } \\
\text { species }\end{array}$ & $\begin{array}{l}\text { Crop } \\
\text { acreage } \\
\text { infested }\end{array}$ & $\begin{array}{l}\text { Noncrop } \\
\text { acreage } \\
\text { infested }\end{array}$ & $\begin{array}{l}\text { Year(s) since first } \\
\text { appearance in crop } \\
\text { fields }\end{array}$ & $\begin{array}{c}\text { Year(s) since first } \\
\text { appearance in noncrop } \\
\text { habitats }\end{array}$ & $\begin{array}{l}\text { Difficulty of } \\
\text { management }\end{array}$ \\
\hline Crop acreage infested & $-^{a}$ & - & $0.62^{* * *}$ & $0.36^{* * *}$ & $0.25^{* * *}$ & $0.29^{* * *}$ \\
\hline $\begin{array}{l}\text { Noncrop acreage } \\
\text { infested } \\
\text { Difficulty of }\end{array}$ & - & $0.62^{* * *}$ & - & $0.26^{* * *}$ & $0.25^{* * *}$ & $0.22^{* * *}$ \\
\hline $\begin{array}{c}\text { management } \\
\text { Resistance to ALS }\end{array}$ & - & $0.29^{* * *}$ & $0.22^{* * *}$ & ns & $\mathrm{ns}$ & - \\
\hline & Corn & $0.18^{* * *}$ & $0.23^{* * *}$ & $0.20^{* * *}$ & $0.21^{* * *}$ & $0.23^{* * *}$ \\
\hline $\begin{array}{l}\text { inhibitors } \\
\text { Resistance to ALS }\end{array}$ & Soybean & $0.19^{* * *}$ & $0.21^{* * *}$ & $0.19^{* * *}$ & $0.17^{* * *}$ & $0.25^{* * *}$ \\
\hline $\begin{array}{l}\text { inhibitors } \\
\text { Resistance to }\end{array}$ & Wheat & $0.19^{* * *}$ & $0.20^{* * *}$ & $0.12^{*}$ & $0.15^{* *}$ & $0.29^{* * *}$ \\
\hline $\begin{array}{r}\text { glyphosate } \\
\text { Resistance to } \\
\text { glyphosate }\end{array}$ & Soybean & $0.14^{* * *}$ & $0.20^{* * *}$ & $0.09^{*}$ & $0.10^{*}$ & $\begin{array}{l}0.24^{* * *} \\
0.24^{* * *}\end{array}$ \\
\hline $\begin{array}{l}\text { Resistance to } \\
\text { glyphosate } \\
\text { Resistance to ALS }\end{array}$ & Wheat & $0.16^{* *}$ & $0.23^{* * *}$ & ns & $0.11^{*}$ & $0.24^{* * *}$ \\
\hline $\begin{array}{l}\text { inhibitors + } \\
\text { glyphosate } \\
\text { Resistance to ALS }\end{array}$ & Corn & $0.15^{* * *}$ & $0.25^{* * *}$ & $0.10^{*}$ & $0.16^{* * *}$ & $0.25^{* * *}$ \\
\hline $\begin{array}{l}\text { inhibitors + } \\
\text { glyphosate } \\
\text { Resistance to ALS }\end{array}$ & Soybean & $0.15^{* * *}$ & $0.22^{* * *}$ & $0.11^{*}$ & $0.14^{* *}$ & $0.27^{* * *}$ \\
\hline $\begin{array}{l}\text { inhibitors + } \\
\text { glyphosate }\end{array}$ & Wheat & $0.18^{* *}$ & $0.18^{* *}$ & ns & ns & $0.23^{* * *}$ \\
\hline
\end{tabular}

${ }^{a}$ Abbreviations: —, no data; ns, not significant; ALS, acetolactate synthase.

* Significance at $\mathrm{P} \leq 0.05$.

** Significance at $\mathrm{P} \leq 0.01$.

*** Significance at $\mathrm{P} \leq 0.001$.

area comprising much of Wisconsin, northern Illinois, and eastern Iowa; most of these reports involved only one type of resistance within a county.

The presence of herbicide-resistant giant ragweed populations in corn, soybean, and wheat fields was positively correlated with giant ragweed abundance (Table 2). These findings are consistent with previous studies that indicated high weed population densities accelerate development of herbicide resistance (Jasieniuk et al. 1996). Herbicide-resistant populations were also correlated with earlier time of appearance of giant ragweed; however, early appearance was more strongly associated with resistance to ALS inhibitors than to glyphosate or to both modes of action (Table 2). A longer and possibly more intensive herbicide use history with regard to giant ragweed could result in greater selection for resistance. ALS inhibitors with substantial activity on giant ragweed were introduced in the mid- to late 1980s (Owen and Zelaya 2005; Tranel and Wright 2002). Between then and 1996, when glyphosateresistant soybean was commercialized (Baylis 2000), selection for resistance to ALS inhibitors would have occurred primarily in areas where giant ragweed first occurred, now more than $20 \mathrm{yr}$ ago. Areas reporting a more recent appearance of giant ragweed may have experienced greater initial selection for glyphosate resistance in glyphosate-tolerant crops, with selection for ALS inhibitor resistance occurring concomitantly or subsequently as glyphosate became less effective.

An unexpected result was the positive correlations of herbicide resistance with giant ragweed abundance and earlier time of appearance in noncrop environments (Table 2). This may reflect the strong correlations between giant ragweed populations in crop fields and noncrop environments discussed earlier. However, it is also possible that noncrop giant 


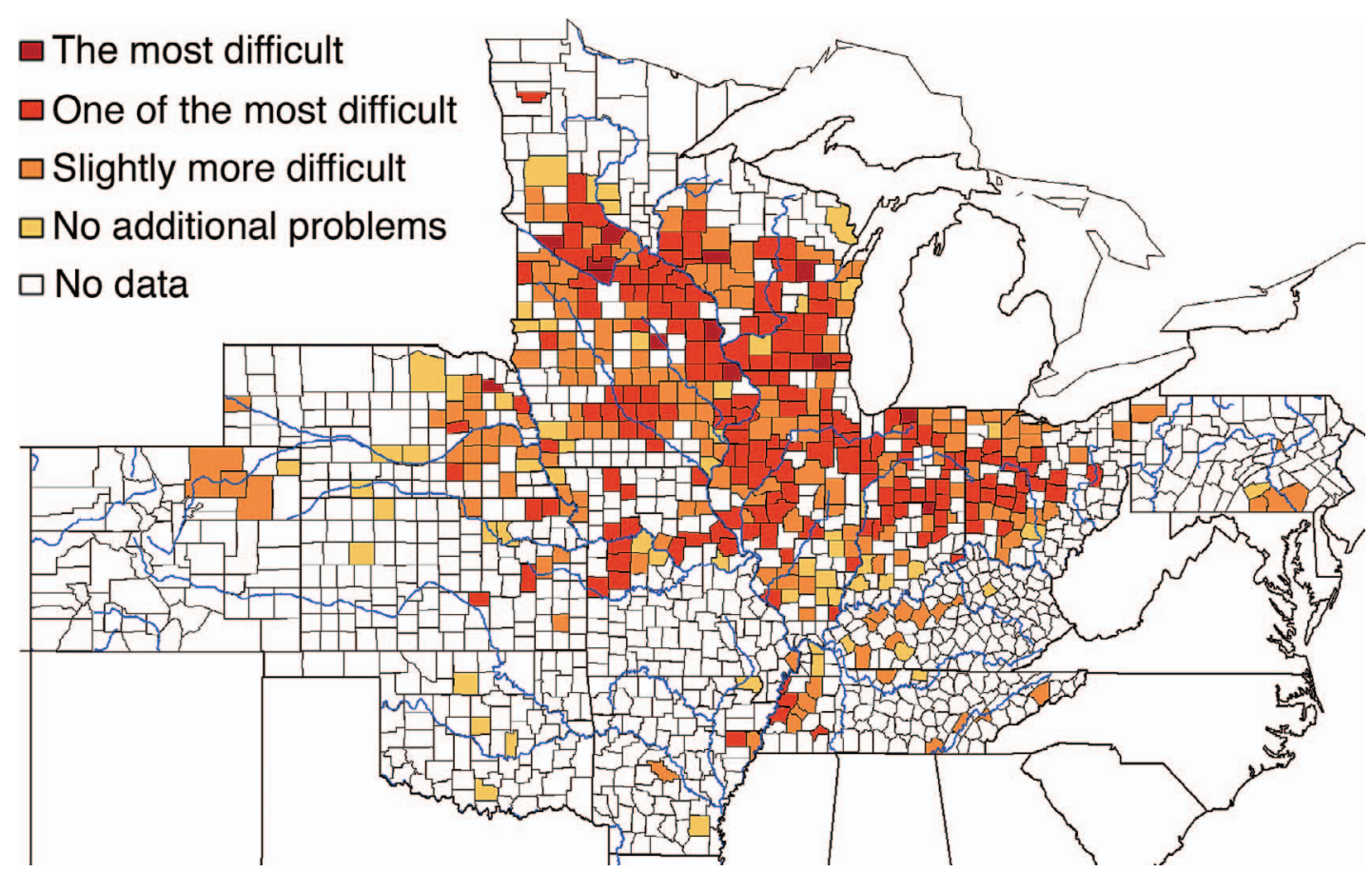

Figure 4. Distribution of survey responses regarding difficulty of managing giant ragweed. For each county, the median response is presented.

ragweed populations may serve as sources of herbicide-resistant biotypes or resistance genes.

Difficulty of Management. Giant ragweed was rated as the most difficult weed to manage in 13 of 421 counties responding, located mainly near the upper Mississippi River in Minnesota, Iowa, and Wisconsin, and in a few counties located in Indiana and Nebraska (Figure 4). Respondents rated giant ragweed as one of the most difficult weeds to manage (but not the most difficult) in 176 counties located mainly in Minnesota, Wisconsin, Iowa, Illinois, Indiana, and Ohio; along the Missouri River from Missouri to Nebraska; and at the Tennessee-Arkansas border along the Mississippi River (Figure 4). These results agree with surveys since the 1990s indicating giant ragweed to be one of the most competitive, problematic, or abundant weeds in Indiana, Iowa, Ohio, and Wisconsin (Fickett et al. 2013a,b; Gibson et al. 2005; Hoskins 2005; Loux and Berry 1991). In addition, giant ragweed has been reported by various researchers to be a growing problem in Arkansas, Missouri, and Tennessee (Barnett and Steckel 2013; Norsworthy et al. 2010, 2011; Riley and Bradley 2014).

Difficulty of managing giant ragweed was correlated with giant ragweed abundance and with herbicide resistance, but not with years since first appearance of giant ragweed in crop fields (Table 2). This was contrary to our expectation that in areas where giant ragweed has been established for a longer period of time, evolution of crop-adapted traits, such as herbicide resistance, would make its management more difficult. The lack of correlation may be due, in part, to the different histories of ALS-inhibitor and glyphosate use, discussed earlier. It may also be due to a history of problems managing giant ragweed in areas within the surveyed region that began well before the time period evaluated in this survey and before development of herbicide resistance (Jordan 1985; Loux and Berry 1991; Page and Nurse 2015).

Tillage Practices. Estimated corn and soybean acreage managed by conventional tillage was negatively correlated with difficulty of managing giant ragweed and with giant ragweed abundance (Table 3), suggesting giant ragweed populations decrease as tillage intensity increases. Estimated corn acreage receiving minimum tillage was positively correlated with both difficulty of management and giant ragweed abundance. Estimated acreage receiving no tillage was not correlated with either management difficulty or giant ragweed abundance. These data support research conducted in Wisconsin (Stoltenberg et al. 2011) and Indiana (Barnes et al. 2004), which showed greater abundance of giant ragweed in agricultural fields with tillage systems that provided an intermediate level of soil disturbance relative to

Regnier et al.: Giant ragweed in the Corn Belt • 
Table 3. Correlation coefficients of correlations between survey responses to questions regarding percentage of crop acreage infested with giant ragweed, difficulty managing giant ragweed, giant ragweed resistance to herbicides, and percentage of crop acreage under various tillage and rotation practices. Questions addressed tillage and crop rotation practices in crop species separately. Crop rotation refers to percentage of crop acreage rotated at least once in the previous 3 yr.

\begin{tabular}{llcccc}
\hline Survey question & Crop species & Conventional tillage & Minimum tillage & No tillage & Rotation \\
\hline Crop acreage infested & Corn & $\mathrm{ns}^{\mathrm{a}}$ & $0.09^{*}$ & $\mathrm{~ns}$ & $\mathrm{~ns}$ \\
Crop acreage infested & Soybean & $-0.12^{*}$ & $\mathrm{~ns}$ & $\mathrm{~ns}$ & $\mathrm{~ns}$ \\
Crop acreage infested & Wheat & $\mathrm{ns}$ & $0.10^{*}$ & $\mathrm{~ns}$ & $\mathrm{~ns}$ \\
Difficulty of management & Corn & $-0.08^{*}$ & $0.12^{* *}$ & $\mathrm{~ns}$ & $-0.10^{* *}$ \\
Difficulty of management & Soybean & $-0.13^{* * *}$ & $\mathrm{~ns}$ & $\mathrm{~ns}$ & $\mathrm{~ns}$ \\
Difficulty of management & Wheat & $\mathrm{ns}$ & $\mathrm{ns}$ & $\mathrm{ns}$ & $\mathrm{ns}$ \\
Resistance to ALS inhibitors & Corn & $\mathrm{ns}$ & $\mathrm{ns}$ & $\mathrm{ns}$ & $\mathrm{ns}$ \\
Resistance to ALS inhibitors & Soybean & $\mathrm{ns}$ & $\mathrm{ns}$ & $0.09^{*}$ & $-0.07^{*}$ \\
Resistance to ALS inhibitors & Wheat & $\mathrm{ns}$ & $\mathrm{ns}$ & $\mathrm{ns}$ & $\mathrm{ns}$ \\
Resistance to glyphosate & Corn & $\mathrm{ns}$ & $\mathrm{ns}$ & $\mathrm{ns}$ & $\mathrm{ns}$ \\
Resistance to glyphosate & Soybean & $\mathrm{ns}$ & $\mathrm{ns}$ & $\mathrm{ns}$ & $-0.12^{* *}$ \\
Resistance to glyphosate & Wheat & $\mathrm{ns}$ & $\mathrm{ns}$ & $\mathrm{ns}$ & $\mathrm{ns}$ \\
Resistance to ALS inhibitors + glyphosate & Corn & $\mathrm{ns}$ & $\mathrm{ns}$ & $-0.10^{*}$ & $\mathrm{~ns}$ \\
Resistance to ALS inhibitors + glyphosate & Soybean & $\mathrm{ns}$ & $\mathrm{ns}$ & $\mathrm{ns}$ & $-0.15^{* *}$ \\
Resistance to ALS inhibitors + glyphosate & Wheat & $\mathrm{ns}$ & $\mathrm{ns}$ & $\mathrm{ns}$ & $\mathrm{ns}$ \\
\hline
\end{tabular}

${ }^{a}$ Abbreviations: ns, not significant; ALS, acetolactate synthase.

* Significance at $\mathrm{P} \leq 0.05$.

** Significance at $\mathrm{P} \leq 0.01$.

*** Significance at $\mathrm{P} \leq 0.001$.

conventional tillage or no-tillage systems. Partial inversion of the soil may provide an optimal depth distribution of giant ragweed seeds to escape seed predators and emerge successfully.

Crop Rotation. Percentage of corn acreage that was rotated was negatively correlated with difficulty in managing giant ragweed, and percentage of soybean acreage that was rotated was negatively correlated with herbicide resistance (Table 3). Percentage of wheat acreage that was rotated was not correlated with either of these variables (Table 3 ). There were no significant correlations of giant ragweed abundance with percentage of corn, soybean, or wheat acreage that was rotated (Table 3). Although these results appear contradictory, participants were asked only to estimate the percentage of crop acreage with giant ragweed present and not the population density. Therefore, the lack of correlation with giant ragweed abundance may reflect the ability of at least some giant ragweed plants to establish in fields of crop species typically grown in the surveyed region or to regenerate from the soil seed bank over a 3-yr period in the absence of annual seed return (Harrison et al. 2007). Overall, the results indicate that either continuous corn or continuous soybean production increases both the difficulty of managing giant ragweed and herbicide-resistant populations, whereas continuous wheat has little impact on giant ragweed problems.
Herbicide Practices. There were significant correlations of various herbicide practices with giant ragweed abundance and resistance, and the majority of these correlations involved giant ragweed management in soybean (Table 4). In corn and soybean fields, giant ragweed abundance was negatively correlated with estimated acreage treated with POST ONLY, but positively correlated with estimated acreage treated with PRE + POST (Table 4). In soybean fields, estimated acreage receiving PRE ONLY or 1 POST was negatively correlated with giant ragweed abundance, but acreage receiving 2 POST was positively correlated with abundance. We interpret these combined responses to mean that corn and soybean growers tend to employ sequential PRE and POST treatments rather than POST ONLY or PRE ONLY treatments in areas with higher levels of giant ragweed infestation, and also that soybean growers are likely to use more than one POST treatment in these areas. In wheat, we observed negative correlations between difficulty of management or abundance and use of POST herbicides (Table 4), which appears to reflect the improved control that occurs when wheat growers decide to use POST herbicides.

In corn and soybean fields, herbicide-resistant giant ragweed was negatively correlated with POST ONLY (Table 4). In soybean fields, herbicide resistance was negatively correlated with 1 POST, but positively correlated with PRE + POST and 2 
Table 4. Correlation coefficients of correlations between survey responses to questions regarding percentage of crop acreage infested with giant ragweed, difficulty managing giant ragweed, giant ragweed resistance to herbicides, and percentage of crop acreage under various herbicide practices. Questions addressed herbicide practices in crop species separately.

\begin{tabular}{|c|c|c|c|c|c|c|c|}
\hline Survey question & Crop species & PRE only & POST only & PRE + POST & $1 \mathrm{POST}^{\mathrm{a}}$ & 2 POST & $>2$ POST \\
\hline Crop acreage infested & Corn & $\mathrm{ns} s^{\mathrm{a}}$ & $-0.12^{* * *}$ & $0.13^{* * *}$ & ns & ns & ns \\
\hline Crop acreage infested & Soybean & $-0.16^{* * *}$ & $-0.07^{*}$ & $0.11^{* *}$ & $-0.09^{*}$ & $0.11^{* *}$ & ns \\
\hline Difficulty of management & Corn & ns & ns & ns & ns & ns & ns \\
\hline Difficulty of management & Soybean & $-0.07^{*}$ & ns & ns & ns & ns & ns \\
\hline Difficulty of management & Wheat & ns & ns & $-0.14^{*}$ & $-0.09^{*}$ & ns & ns \\
\hline Resistance to ALS inhibitors & Wheat & ns & $-0.16^{* *}$ & ns & $-0.13^{* *}$ & ns & ns \\
\hline Resistance to glyphosate & Corn & ns & $-0.11^{* *}$ & ns & ns & ns & ns \\
\hline Resistance to glyphosate & Soybean & $\mathrm{ns}$ & $-0.13^{* * *}$ & $0.14^{* * *}$ & $-0.13^{* * *}$ & $0.12^{* *}$ & $0.11^{* *}$ \\
\hline Resistance to glyphosate & Wheat & ns & ns & ns & ns & ns & ns \\
\hline Resistance to ALS inhibitors + glyphosate & Corn & $0.13^{* *}$ & $-0.14^{* *}$ & ns & $-0.13^{* *}$ & $-0.10^{*}$ & $0.09^{*}$ \\
\hline Resistance to ALS inhibitors + glyphosate & Soybean & ns & $-0.18^{* * *}$ & $0.18^{* * *}$ & $-0.12^{* *}$ & $0.10^{*}$ & $0.11^{*}$ \\
\hline
\end{tabular}

${ }^{a}$ Abbreviations: 1 POST, one POST application; 2 POST, two POST applications; > 2 POST, more than two POST applications; ns, not significant; ALS, acetolactate synthase.

* Significance at $\mathrm{P} \leq 0.05$.

** Significance at $\mathrm{P} \leq 0.01$.

*** Significance at $\mathrm{P} \leq 0.001$.

POST (Table 4). These responses may indicate that a single POST herbicide in either corn or soybean is generally effective for giant ragweed management until resistant populations develop, after which PRE herbicides, multiple POST treatments, or both are needed to obtain effective control.

Considering crop production practices as a whole, the results suggest that increased frequency of soybean in a crop rotation and minimum tillage increase giant ragweed populations and management difficulty. Giant ragweed can be more difficult to manage in soybean than in corn or wheat (Page and Nurse 2015). There are fewer effective herbicide sites of action for PRE or POST application in soybean compared with corn and wheat, and resistance to glyphosate or ALS inhibitors leaves even fewer alternative herbicide options for management. Giant ragweed is also especially difficult to manage under no-tillage conditions, due in part to the need for effective preplant foliar treatments to control earlyemerging weeds. It is possible to control low-density, herbicide-sensitive giant ragweed populations adequately with a single-application POST-only herbicide program in corn or soybean (Loux et al. 2015), but higher weed densities result in the need for a more comprehensive management approach, which may involve use of PRE and POST herbicides, and in soybean, multiple POST herbicide applications (Stachler et al. 2008).
Survey results indicate that where dense giant ragweed infestations or herbicide-resistant populations exist, herbicide applications are more frequent. For most farmers, changing herbicide programs is easier than changing other aspects of their production system, so it is usually the first step taken to respond to shifts in weed communities. However, multiple applications of POST herbicides with the same site of action would exert considerable selection pressure for resistance. The presence of one or more types of herbicide resistance may encourage multiple applications of PRE and POST herbicides in an effort to regain control of giant ragweed, creating a feedback loop that speeds resistance development. Inclusion of alternative trait technologies in the crop rotation, such as crop resistance to glufosinate, growth regulator, and 4-hydroxyphenuyl-pyruvate dioxygenase inhibitors could be useful tools to prevent or manage herbicide resistance (Craigmyle et al. 2013; Kaur et al. 2014). However, given the genetic diversity of giant ragweed and the rapid development of herbicide-resistant populations throughout the Corn Belt, use of alternative-trait herbicides alone (in the absence of diversified tillage and rotation practices) is likely to be a short-term solution where infestations are dense or resistance is already present.

Ecological Factors. Habitat. The proportion of crop area with giant ragweed present was associated with its presence in both riparian and upland

Regnier et al.: Giant ragweed in the Corn Belt • 371 
Table 5. Correlation coefficients of correlations between survey responses to questions regarding percentage of crop acreage infested with giant ragweed, difficulty managing giant ragweed, giant ragweed resistance to herbicides, and presence of giant ragweed within a specific noncrop habitat type. Questions regarding crop acreage infested and difficulty of management addressed crop species collectively. Questions regarding herbicide resistance addressed crop species separately.

\begin{tabular}{|c|c|c|c|c|c|c|c|c|c|}
\hline Survey question & Crop & Riverbanks & Floodplains & $\begin{array}{l}\text { Ditch } \\
\text { banks }\end{array}$ & Waterways & Railroads & Roadsides & $\begin{array}{l}\text { Forest } \\
\text { borders }\end{array}$ & Fencerows \\
\hline Crop acreage infested & $-^{\mathrm{a}}$ & $0.16^{* * *}$ & $0.22^{* * *}$ & $0.14^{* * *}$ & $0.22^{* * *}$ & $0.18^{* * *}$ & $0.15^{* * *}$ & $0.22^{* * *}$ & $0.13^{* * *}$ \\
\hline $\begin{array}{l}\text { Difficulty of management } \\
\text { Resistance to ALS }\end{array}$ & - & $0.11^{* * *}$ & $0.10^{* *}$ & $0.10^{* *}$ & $0.19^{* * *}$ & $\mathrm{~ns}$ & $0.09^{* *}$ & $0.11^{* * *}$ & $0.11^{* * *}$ \\
\hline $\begin{array}{l}\text { Resistance to ALS } \\
\text { inhibitors } \\
\text { Resistance to ALS }\end{array}$ & Corn & $0.13^{* *}$ & $0.13^{* * *}$ & $0.12^{* *}$ & $0.13^{* *}$ & $0.22^{* * *}$ & $0.10^{*}$ & $0.16^{* * *}$ & $0.17^{* * *}$ \\
\hline $\begin{array}{l}\text { inhibitors } \\
\text { Resistance to ALS }\end{array}$ & Soybean & $0.11^{*}$ & ns & $0.10^{*}$ & $0.10^{*}$ & $0.18^{* * *}$ & $0.10^{*}$ & $0.13^{* *}$ & $0.16^{* * *}$ \\
\hline inhibitors & Wheat & ns & ns & $0.19^{* * *}$ & $0.11^{*}$ & $0.24^{* * *}$ & $0.11^{*}$ & $0.16^{* *}$ & $0.21^{* * *}$ \\
\hline Resistance to glyphosate & Corn & $0.12^{* *}$ & $0.13^{* * *}$ & $0.16^{* * *}$ & $0.09^{*}$ & $0.16^{* * *}$ & $0.14^{* * *}$ & $0.10^{*}$ & $0.12^{* *}$ \\
\hline Resistance to glyphosate & Soybean & $0.10^{*}$ & $0.10^{*}$ & $0.15^{* * *}$ & ns & $0.15^{* * *}$ & $0.14^{* * *}$ & $0.10^{*}$ & $0.11^{* *}$ \\
\hline $\begin{array}{l}\text { Resistance to glyphosate } \\
\text { Resistance to ALS }\end{array}$ & Wheat & ns & ns & $0.21^{* * *}$ & ns & $0.21^{* * *}$ & $0.13^{*}$ & $0.16^{* *}$ & $0.15^{* *}$ \\
\hline $\begin{array}{l}\text { inhibitors + glyphosate } \\
\text { Resistance to ALS }\end{array}$ & Corn & $0.14^{* *}$ & $0.11^{* *}$ & $0.15^{* * *}$ & $0.11^{* *}$ & $0.23^{* * *}$ & $0.12^{* *}$ & $0.15^{* * *}$ & $0.13^{* *}$ \\
\hline $\begin{array}{l}\text { inhibitors + glyphosate } \\
\text { Resistance to ALS }\end{array}$ & Soybean & $0.11^{*}$ & ns & $0.13^{* *}$ & ns & $0.19^{* * *}$ & $0.13^{* *}$ & $0.11^{* *}$ & $0.14^{* *}$ \\
\hline inhibitors + glyphosate & Wheat & ns & ns & $0.14^{* *}$ & ns & $0.18^{* * *}$ & $0.12^{*}$ & $0.11^{*}$ & $0.15^{* *}$ \\
\hline
\end{tabular}

${ }^{\text {a }}$ Abbreviations: —, no data; ns, not significant; ALS, acetolactate synthase.

* Significance at $\mathrm{P} \leq 0.05$.

** Significance at $\mathrm{P} \leq 0.01$.

*** Significance at $\mathrm{P} \leq 0.001$.

noncrop habitats, especially floodplains, waterways, forest borders, and railroad sidings (Table 5). Management difficulty, however, was most strongly correlated with giant ragweed occurrence in waterways. As a native riparian species, giant ragweed establishment is favored by moist environments (Korres et al. 2015a), and managing giant ragweed may be particularly difficult where wet soil conditions impede access. Such populations could be recurring sources of seed dispersal into adjacent fields. The data provide evidence that giant ragweed is adapted to both riparian and upland edge habitats across the U.S. Corn Belt, increasing its potential to disperse over long distances through continuous edge habitats and over short distances from field margins into crop fields.

The presence of herbicide-resistant giant ragweed populations in crop fields correlated most strongly with its occurrence in railroad sidings, but also with its occurrence in ditch banks and fencerows (Table 5). Few significant correlations were found between herbicide-resistant populations and giant ragweed occurrence in riverbanks, floodplains, or waterways (Table 5). Based on these responses, it appears herbicide-resistant populations in crop fields are associated with noncrop giant ragweed populations in somewhat drier, linear corridors associated with crop field edges and transportation routes. Noncrop populations may facilitate movement of seeds or resistant genes from field to field (Mallory-Smith and Zapiola 2008). Glyphosate-resistant gene flow in giant ragweed is mediated by pollen and seed, and outcrossing rates of $31 \%$ were detected at a distance of $76 \mathrm{~cm}$ (Brabham et al. 2011). Recent research in Wisconsin indicated the absence of a fecundity penalty for glyphosate-resistant giant ragweed biotypes compared to sensitive biotypes (Glettner and Stoltenberg 2015), suggesting that resistant biotypes may persist in the absence of selection by glyphosate. Research is needed to determine the extent to which herbicide resistance genes may occur and persist in noncrop habitats.

Control of plants in noncrop areas may help prevent new infestations in areas where crop fields are rarely infested. The survey respondents' perceptions that giant ragweed is one of the most difficult weeds to manage could be coupled with efforts to educate growers that controlling giant ragweed in noncrop areas can reduce the potential for its introduction into crop fields. Korres et al. (2015b) advocate such an approach for preventing the spread of herbicideresistant weeds in the eastern Arkansas Mississippi Delta. Research on the impact of different management regimes for giant ragweed occurring in field borders and its migration into crop fields could be useful in discovering methods to prevent giant ragweed establishment at the "whole-farm" level. 


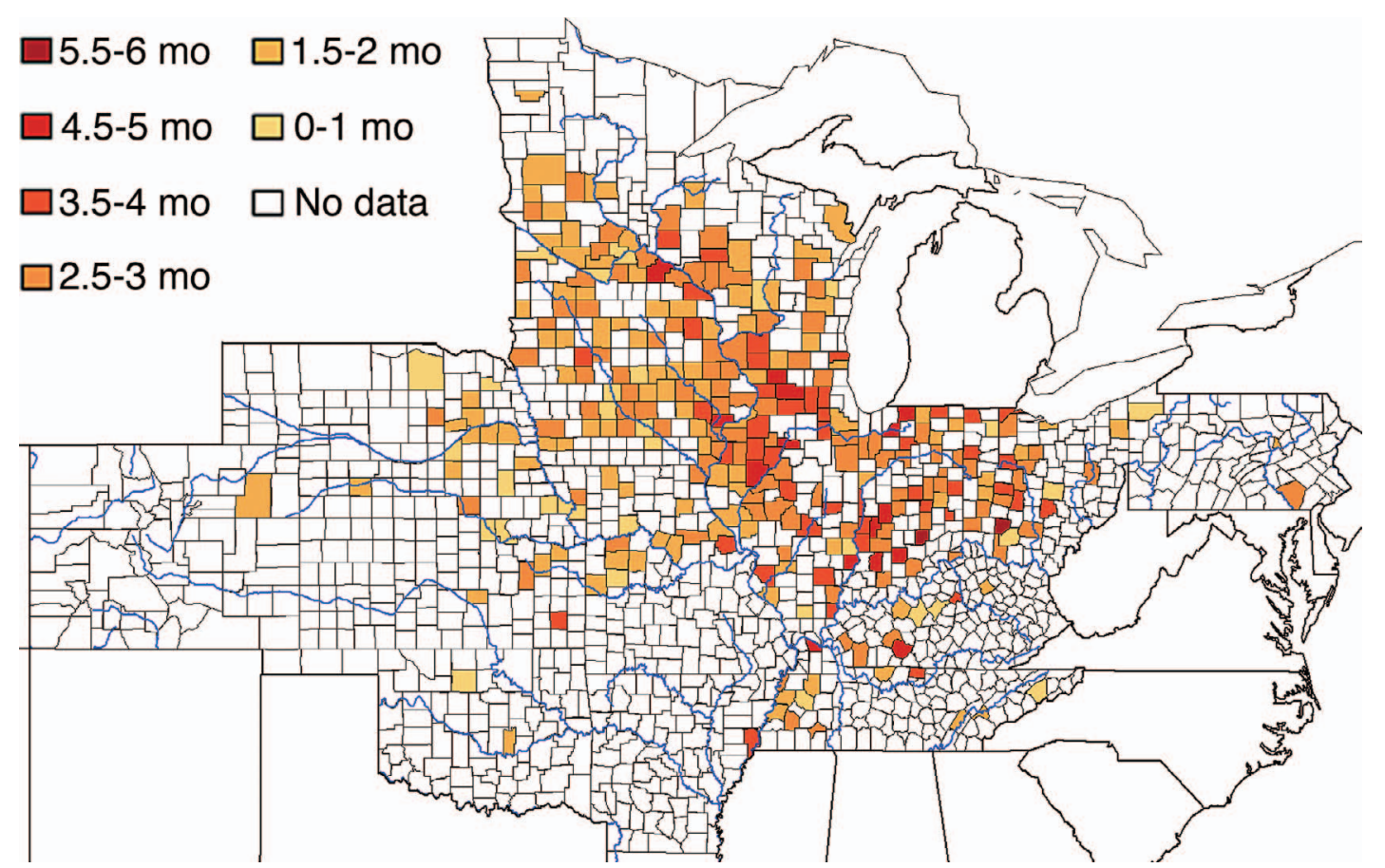

Figure 5. Distribution of emergence period of giant ragweed, in months. Emergence period was calculated from responses to survey questions asking respondents to select the month of earliest emergence and the month of latest emergence observed in their county. Emergence period was calculated by subtracting the month of earliest emergence from the month of last emergence. For each county, the median response is presented.

Emergence. Counties reporting giant ragweed emergence periods of 3.5 mo or longer were distributed primarily in Ohio, Indiana, Illinois, and Wisconsin, whereas counties reporting emergence periods of $\leq 2$ mo were located mostly west of the Mississippi River (Figure 5), consistent with earlier reports (Kaur 2015; Schutte et al. 2012; Sprague et al. 2004; Werle et al. 2014; Wuerffel et al. 2015) and the hypothesis of an east-to-west trend in emergence period. Giant ragweed abundance and difficulty of management were both correlated with earlier and longer periods of giant ragweed emergence

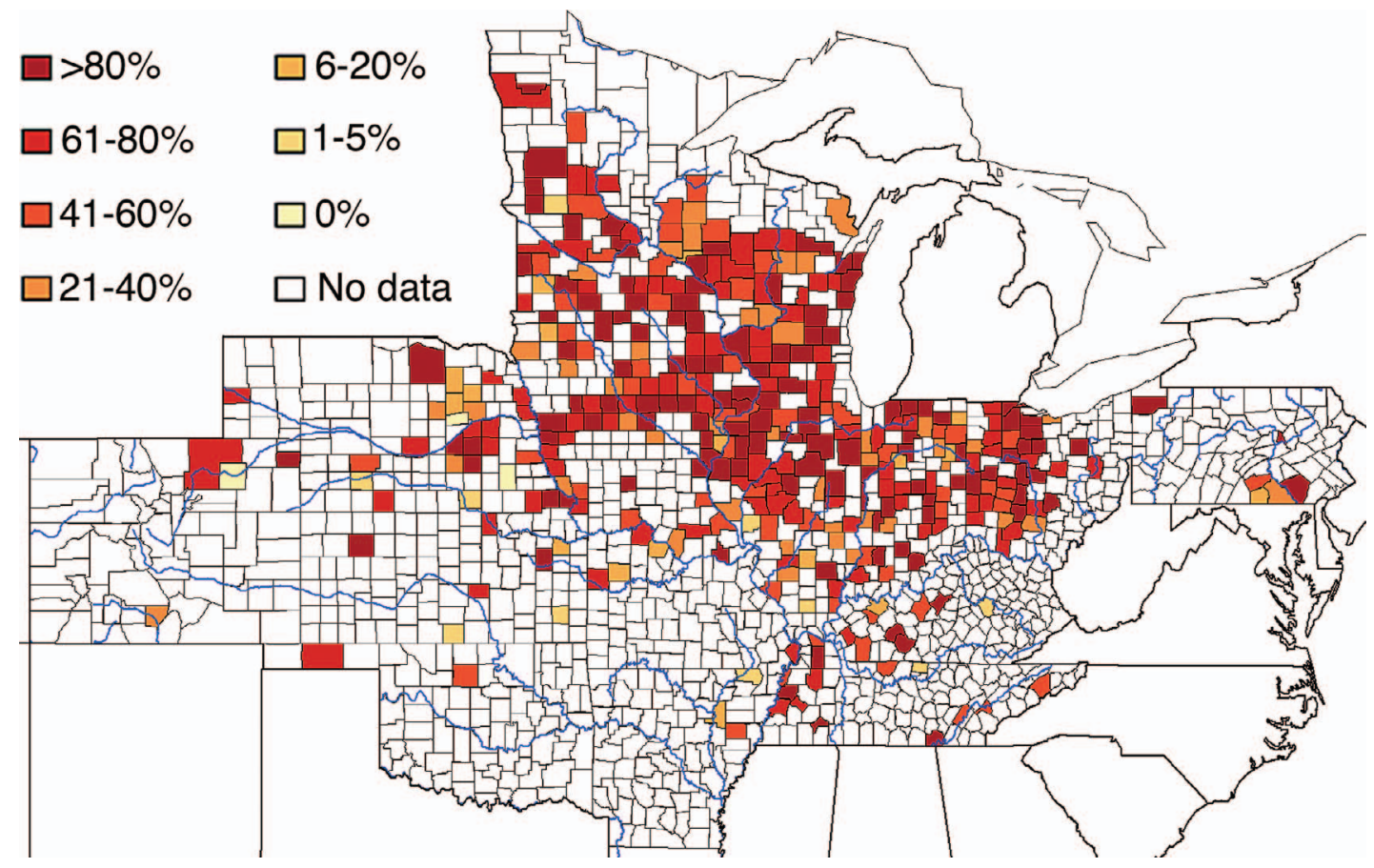

Figure 6. Distribution of survey responses regarding percentage of acreage with common earthworm present in crop fields. For each county, the median response is presented. 
Table 6. Correlation coefficients of correlations between survey responses to questions regarding percentage of crop acreage infested with giant ragweed, difficulty managing giant ragweed, giant ragweed resistance to herbicides, giant ragweed emergence characteristics and presence of the common earthworm. Questions regarding crop acreage infested and difficulty of management addressed crop species collectively. Questions regarding herbicide resistance addressed crop species separately.

\begin{tabular}{|c|c|c|c|c|c|}
\hline Survey question & Crop & $\begin{array}{c}\text { Month of first } \\
\text { emergence }\end{array}$ & $\begin{array}{c}\text { Month of last } \\
\text { emergence }\end{array}$ & $\begin{array}{l}\text { Period of } \\
\text { emergence }\end{array}$ & $\begin{array}{l}\text { Common } \\
\text { earthworm }\end{array}$ \\
\hline Crop acreage infested & $\underline{-}^{\mathrm{a}}$ & $-0.14^{\mathrm{b} * * *}$ & ns & $0.33^{\mathrm{c} * * *}$ & $0.22^{* * *}$ \\
\hline Resistance to ALS inhibitors & Corn & $-0.13^{*}$ & $0.08^{*}$ & $0.17^{* * *}$ & ns \\
\hline Resistance to ALS inhibitors & Soybean & $-0.14^{*}$ & $0.04^{*}$ & $0.13^{* *}$ & ns \\
\hline Resistance to ALS inhibitors & Wheat & $-0.24^{* * *}$ & ns & $0.16^{* *}$ & ns \\
\hline Resistance to glyphosate & Wheat & ns & ns & ns & ns \\
\hline $\begin{array}{l}\text { Resistance to ALS inhibitors + } \\
\text { glyphosate }\end{array}$ & Corn & $-0.17^{* *}$ & $-0.02^{* *}$ & $0.23^{* * *}$ & ns \\
\hline $\begin{array}{l}\text { Resistance to ALS inhibitors + } \\
\text { glyphosate }\end{array}$ & Soybean & $-0.16^{* *}$ & $-0.06^{* *}$ & $0.18^{* * *}$ & ns \\
\hline $\begin{array}{l}\text { Resistance to ALS inhibitors + } \\
\text { glyphosate }\end{array}$ & Wheat & $-0.16^{*}$ & ns & $0.17^{* *}$ & ns \\
\hline
\end{tabular}

a Abbreviations: - , no data; ns, not significant; ALS, acetolactate synthase.

${ }^{\mathrm{b}}$ A negative correlation indicates earlier month of emergence.

${ }^{\mathrm{c}}$ A positive correlation indicates a longer period of emergence.

* Significance at $\mathrm{P} \leq 0.05$.

** Significance at $\mathrm{P} \leq 0.01$.

*** Significance at $\mathrm{P} \leq 0.001$.

(Table 6). Resistance to ALS inhibitors and resistance to both ALS inhibitors and glyphosate were also correlated with earlier and longer emergence periods (Table 6). Difficulty of management and resistance to ALS inhibitors were associated with later month of last emergence (Table 6). These results support the hypothesis that giant ragweed problems are associated with longer emergence periods, due to both early and late-emerging giant ragweed.

As giant ragweed populations become established in agricultural fields, it seems likely that the prolonged-emergence adaptation will increase and spread over time if those populations are allowed to persist. An understanding that giant ragweed emergence phenology can vary widely among populations across the region should alert growers to the necessity of vigilance for late-emerging weeds that can impact crop yield, contribute to the seed bank, and exacerbate herbicide resistance management. Where populations with prolonged emergence already exist, weed management beyond early-season treatments will likely be necessary to prevent seed return by late-emerging phenotypes.

Earthworm Abundance. The proportion of crop acreage with common earthworms present was associated with giant ragweed abundance (Table 6), supporting previous observations of an association between the two species in no-tillage crop fields (Schutte et al. 2010), and the hypothesis that common earthworm facilitates giant ragweed establishment by burying seeds in its burrows (Regnier et al. 2008). Approximately $64 \%$ of respondents indicated over $40 \%$ of crop acreage had common earthworms present, and $36 \%$ indicated more than $80 \%$ of crop acreage had earthworms present (Figure 6; Supplemental Appendix 2: http://dx.doi.org/10.1614/WS-D-1500116.S2). The association of the two species may contribute to the positive correlation observed between minimum tillage and giant ragweed management difficulty, discussed earlier.

\section{Implications}

As a whole, the data support the hypothesis that giant ragweed distribution over the Corn Belt correlates with geographic variation in agricultural practices and ecological factors. In general, there were fewer positive correlations of management practices with giant ragweed management difficulty and herbicide resistance in wheat than in corn or soybean. Management difficulty and herbicide resistance were most strongly associated with soybean and minimum tillage.

Several authors have called for an integrated management approach for the control of (glyphosateresistant or susceptible) giant ragweed (Glettner and Stoltenberg 2015; Kaur et al. 2014; Page and Nurse 2015). Management strategies to combat those most 
problematic giant ragweed populations could include use of a fall-seeded cover crop or incorporation of a fall- or spring-seeded cereal grain into the normal corn-soybean crop rotation sequence most commonly followed in the U.S. Corn Belt. Either of these strategies could provide additional soil cover during the giant ragweed emergence period, although growers should be aware that use of ALS inhibitors in small grains could exacerbate herbicide resistance problems in rotational crops. Winter annual cover crops have been reported to inhibit weed seedling emergence (Moore et al. 1994). Schutte (2008) found that giant ragweed seeds lose viability at $20 \mathrm{C}$ and suggested that giant ragweed seeds that do not germinate in the spring are susceptible to decay in the summer. Prevention of early giant ragweed germination by cover crops or cereal grains could promote decay of nongerminated or dormant giant ragweed seeds in soil over the summer months. Winter cereal grains or cover crops would also provide multiple chemical or mechanical control options for giant ragweed control (Mahoney et al. 2015). The effect of cover crops and cereal grains on late- vs. early-emerging giant ragweed populations warrants investigation. Research on the effects of diversified crop rotations and rotation of tillage practices on giant ragweed populations over a period of at least 3 yr could provide useful information for developing future management strategies.

\section{Acknowledgments}

This project was supported by the National Research Initiative of the U.S. Department of Agriculture Cooperative State Research, Education and Extension Service, GRANT11073659 and GRANT10356701. We are grateful for the efforts of Dr. Christopher Boerboom to secure the initial funding and the professional facilitation of the research team by Dr. Joseph Heimlich. Salaries and research support were provided by state and federal funds appropriated to the Ohio Agricultural Research and Development Center, grant number 2011-078. Journal article HCS15-18.

\section{Literature Cited}

Abul-Fatih HA, Bazzazz FA (1979) The biology of Ambrosia trifida L. I. Influence of species removal on the organization of the plant community. New Phytol 83:813-816

Arbes SJ Jr, Gergen PJ, Elliott L, Zeldin DC (2005) Prevalences of positive skin test responses to 10 common allergens in the U.S. population: results from the third National Health and Nutrition Examination Survey. J Allergy Clin Immunol 116:377-383
Asmus A, Clay SA, Ren C (2013) Summary of certified crop advisors' response to a weed resistance survey. Agron J 105:1160-1166

Barnes J, Johnson B, Gibson K, Weller S (2004) Crop rotation and tillage system influence late-season incidence of giant ragweed and horseweed in Indiana soybean. Crop Manag DOI:10.1094/CM-2004-0923-02-BR

Barnett KA, Steckel LE (2013) Giant ragweed (Ambrosia trifida) competition in cotton. Weed Sci 61:543-548

Bassett I, Crompton C (1982) The biology of Canadian weeds. 55. Ambrosia trifida L. Can J Plant Sci 62:1003-1010

Baylis AD (2000) Why glyphosate is a global herbicide: strengths, weaknesses, and prospects. Pest Manag Sci 56:299-308

Baysinger JA, Sims BD (1991) Giant ragweed (Ambrosia trifida) interference in soybeans (Glycine max). Weed Sci 39:358-362

Brabham CB, Gerber CK, Johnson WG (2011) Fate of glyphosate-resistant giant ragweed (Ambrosia trifida) in the presence and absence of glyphosate. Weed Sci 59:506-511

Boulet L-P, Turcotte H, Laprise C, Lavertu C, Bedard P-M, Lavoie A, Hebert J (1997) Comparative degree and type of sensitization to common indoor and outdoor allergens in subjects with allergic rhinitis and/or asthma. Clin Exp Allergy 27:52-59

Chauvel B, Dessaint F, Cardinal-Legrand C, Bretagnolle F (2006) The historical spread of Ambrosia artemisiffolia L. in France from herbarium records. J Biogeogr 33:665-673

Craigmyle BD, Ellis JM, Bradley KW (2013) Influence of herbicide program on weed management in soybean with resistance to glufosinate and 2,4-D. Weed Technol 27:78-84

[CTIC] Conservation Tillage Information Center. (2012) National Crop Residue Management Survey Conservation Tillage Data. http://www.ctic.purdue.edu/CRM/. Accessed February 22, 2012

Dauer JT, Luschei EC, Mortensen DA (2009) Effects of landscape composition on spread of an herbicide-resistant weed. Landscape Ecol 24:735-747

Davis AS, Clay S, Cardina J, Dille A, Forcella F, Lindquist J, Sprague C (2013) Seed burial physical environment explains departures from regional hydrothermal model of giant ragweed (Ambrosia trifida) seedling emergence in U.S. Midwest. Weed Sci 61:415-421

Edwards CA, Bohlen PJ (1996) Biology and ecology of earthworms. London: Chapman and Hall. $426 \mathrm{pp}$

Fickett ND, Boerboom CM, Stoltenberg DE (2013a) Predicted corn yield loss due to weed competition prior to postemergence herbicide application on Wisconsin farms. Weed Technol 27:54-62

Fickett ND, Boerboom CM, Stoltenberg DE (2013b) Soybean yield loss potential associated with early-season weed competition across 64 site-years. Weed Sci 61:500-507

Gibson KD, Johnson WG, Hillger DE (2005) Farmer perceptions of problematic corn and soybean weeds in Indiana. Weed Technol 19:1065-1070

Glettner CE, Stoltenberg DE (2015) Noncompetitive growth and fecundity of Wisconsin giant ragweed resistant to glyphosate. Weed Sci 63:273-281

Harrison SK, Regnier EE, Schmoll JT (2003) Postdispersal predation of giant ragweed (Ambrosia trifida) seed in no-tillage corn. Weed Sci 51:955-964

Harrison SK, Regnier EE, Schmoll JT, Harrison JM (2007) Seed size and burial effects on giant ragweed (Ambrosia trifida) emergence and seed demise. Weed Sci 55:16-22

Regnier et al.: Giant ragweed in the Corn Belt • 
Harrison SK, Regnier EE, Schmoll JT, Webb JE (2001) Competition and fecundity of giant ragweed in corn. Weed Sci 49:224-229

Heap I (2015) The International Survey of Herbicide Resistant Weeds. http://www.weedscience.org/Summary/home.aspx. Accessed March 7, 2015

Hoskins T (2005) Giant Ragweed a Survivor. http://www. iowafarmertoday.com/news/crop/giant-ragweed-a-survivor/article_ baabd0f3-ea89-5828-8d28-39dd49ad08f6.html. Accessed May 1, 2015

Jasieniuk M, Brûlé-Babel AL, Morrison IN (1996) The evolution and genetics of herbicide resistance in weeds. Weed Sci 44:176-193

Johnson B, Loux MM, Nordby D, Sprague C, Nice G, Westhoven A, Stachler J (2006) Biology and Management of Giant Ragweed. West Lafayette, IN: Purdue Extension Publication GWC-12. $14 \mathrm{p}$

Jordan TN (1985) Weed survey of the North Central Weed Control Conference. North Central Weed Science Society Research Report. Pp 344-355

Kaur S (2015) Biology and Control of Glyphosate-Resistant Giant Ragweed. M.S. thesis. Lincoln, NE: University of Nebraska. 108 p

Kaur S, Sandell LD, Lindquist JL, Jhala AJ ( 2014) Glyphosateresistant giant ragweed (Ambrosia trifida) control in glufosinate-resistant soybean. Weed Technol 28:569-577

Korres NE, Norsworthy JK, Bagavathiannan MV, Mauromoustakos A (2015a) Distribution of arable weed populations along eastern Arkansas Mississippi Delta roadsides: occurrence, distribution, and favored growth habitats. Weed Technol 29:587-595

Korres NE, Norsworthy JK, Bagavathiannan MV, Mauromoustakos A (2015b) Distribution of arable weed populations along eastern Arkansas-Mississippi Delta roadsides: factors affecting weed occurrence. Weed Technol 29:596-604

Kucharik CJ (2008) Contribution of planting date trends to increased maize yields in the central United States. Agron J 100: 328-336

Lavoie C, Jodoin Y, De Merlis AG (2007) How did common ragweed (Ambrosia artemisiifolia L.) spread in Québec? A historical analysis using herbarium records. J Biogeogr 34:1751-1761

Liu J, Regnier E, Harrison K, Holloman C, Schmoll J, Diekmann F, Barker D (2008) Net influence of earthworms (Lumbricus terrestris) on giant ragweed (Ambrosia trifida) seedling recruitment. Abstracts Weed Science Society Am 47:268 [Abstract]

Loux, MM, Berry MA (1991) Use of a grower survey for estimating weed problems. Weed Technol 5:460-466

Loux MM, Doohan D, Dobbels AF, Johnson WJ, Young BG, Legleiter TR, Hager A (2015) Weed Control Guide for Ohio, Indiana, and Illinois. http://corn.osu.edu/specialists/ weeds/specialist-links/2010\%20Weed\%20Control\%20Guide. pdf/view. Accessed July 3, 2015

Mahoney KJ, McNaughton KE, Sikkema PH (2015) Control of glyphosate-resistant giant ragweed in winter wheat. Weed Technol 29:868-873

Mallory-Smith C, Zapiola M (2008) Gene flow from glyphosateresistant crops. Pest Manag Sci 68:428-440

Moore, MJ, Gillespie TJ, Swanton CJ (1994) Effect of cover crop mulches on weed emergence, weed biomass, and soybean $(G l y-$ cine max) development. Weed Technol 8:512-518

Norsworthy JK, Jha P, Steckel LE, Scott RC (2010) Confirmation and control of glyphosate-resistant giant ragweed (Ambrosia trifida) in Tennessee. Weed Technol 24:64-70
Norsworthy JK, Riar D, Jha P, Scott RC (2011) Confirmation, control, and physiology of glyphosate-resistant giant ragweed (Ambrosia trifida) in Arkansas. Weed Technol 25:430-435

Owen MDK, Zelaya IA (2005) Herbicide-resistant crops and weed resistance to herbicides. Pest Manag Sci 61:301-311

Page ER, Nurse RE (2015) Cropping systems and the prevalence of giant ragweed (Ambrosia trifida): from the 1950s to present. Field Crops Res 184:104-111

Patzoldt WL, Tranel PJ (2002) Molecular analysis of cloransulam resistance in a population of giant ragweed. Weed Sci 50: 299-305

Pysek P, Prach K (1995) Invasion dynamics of Impatiens glandulifera-a century of spreading reconstructed. Biol Conserv 74:41-48

Recker RA, Mitchell PD, Stoltenberg DE, Lauer JG, Davis VM (2015) Late-season weed escape survey reveals discontinued atrazine use associated with greater abundance of broadleaf weeds. Weed Technol 29:451-463

Regnier E, Edwards CA, Arancon N, Holloman C, Harrison SK, Liu J, Schmoll JT (2008) Impact of an exotic earthworm on seed dispersal of an indigenous U.S. weed. J Appl Ecol 45:1621-1629

Riley EB, Bradley KW (2014) Influence of application timing and glyphosate tank-mix combinations on the survival of glyphosate-resistant giant ragweed (Ambrosia trifida) in soybean. Weed Technol 28:1-9

Schutte BJ (2008) Biology and Ecology of Ambrosia trifida L. Seedling Emergence. Ph.D dissertation. Columbus, $\mathrm{OH}$ : Ohio State University. $163 \mathrm{p}$

Schutte BJ, Harrison SK, Regnier EE (2008a) The association between seed size and seed longevity among maternal families in Ambrosia trifida L. populations. Seed Sci Res 18:201-211

Schutte BJ, Liu J, Davis AS, Harrison SK, Regnier EE (2010) Environmental factors that influence the association of an earthworm (Lumbricus terrestris L.) and an annual weed (Ambrosia trifida L.) in no-till agricultural fields across the eastern U.S. Corn Belt. Agric Ecosys Environ 138:197-205

Schutte BJ, Regnier EE, Harrison SK (2012) Seed dormancy and adaptive seedling emergence timing in giant ragweed (Ambrosia trifida). Weed Sci 60:19-26

Schutte BJ, Regnier EE, Harrison SK, Schmoll JT, Spokas K, Forcella F (2008b) A hydrothermal seedling emergence model for giant ragweed (Ambrosia trifida). Weed Sci 56:555-560

Sosnoskie LM, Luschei EC, Fanning MA (2007) Field margin weed species diversity in relation to landscape attributes and adjacent land use. Weed Sci 55:129-136

Sprague CL, Wax LM, Hartzler RG, Harrison SK (2004) Variations in emergence patterns of giant ragweed biotypes from Ohio, Illinois, and Iowa. Abstr Weed Sci Soc Am 44:60 [Abstract]

Stachler JM, Loux MM, Dobbels AF (2008) Giant ragweed (Ambrosia trifida) with resistance to multiple herbicide sites of action. Abstr Weed Sci Soc Am 48:26 [Abstract]

Steckel LE, Gwathmey CO (2007) Giant Ragweed. University of Tennessee Fact Sheet. W119. https://utextension. tennessee.edu/publications/documents/w119.pdf. Accessed July 22, 2015

Stoltenberg DE, Sivesind EC, Jeschke MR (2011) Cropping system effects on giant ragweed. Proceedings North Central Weed Science Society 66:162

[USDA-NASS] U.S. Department of Agriculture-National Agricultural Statistics Service (2015) Statistics by Subject-Field 
Crops. http://www.nass.usda.gov/StatisticsbySubject/index.php? sector $=$ CROPS. Accessed October 5, 2015

Venkatesh R, Ford RA, Regnier EE, Harrison SK, Holloman C, Taylor R, Diekmann F (2013) Historical distribution of giant ragweed and common cocklebur in the North Central region. Proc North Central Weed Sci Soc 68:74

Vink JP, Soltani N, Robinson DE, Tardif FJ, Lawton M, Sikkema $\mathrm{PH}$ (2012) Occurrence and distribution of glyphosate-resistant giant ragweed (Ambrosia trifida L.) in southwestern Ontario. Can J Plant Sci 92:533-539

Webster TM, Loux MM, Regnier EE, Harrison SK (1994) Giant ragweed (Ambrosia trifida) canopy architecture and interference studies in soybean (Glycine max). Weed Technol 8:559-564
Werle R, Sandell LD, Buhler DD, Hartzler RG, Lindquist JL (2014) Predicting emergence of 23 summer annual weed species. Weed Sci 62:267-279

Wuerffel RJ, Young JM, Matthews JL, Davis VM, Johnson WG, Young BG. 2015. Timing of soil-residual herbicide applications for control of giant ragweed (Ambrosia trifida). Weed Technol 29:771-781

Received July 10, 2015, and approved October 22, 2015.

Associate Editor for this paper: Theodore Webster, USDA-ARS. 